\title{
IbM KELOMPOK WANITA TANI BABATAN APLIKASI BOKHASI PLUS UNTUK BUDIDAYA CABE
}

\author{
IbM BABATAN'S FEMALE FARM GROUP BOKHASI PLUS \\ APPLICATIONS ON CHILI CULTIVATION
}

\author{
Oleh: \\ Nurlianti ${ }^{1)}$, Prihanani ${ }^{2)}$ \\ 1) Jurusan Agroteknologi, Fakultas Pertanian, Unihaz \\ ${ }^{2)}$ Jurusan Teknologi Pertanian, Fakultas Pertanian, Unihaz \\ Email: nurlianti.pertiwi@gmail.com
}

\begin{abstract}
Problems faced by the group of partners as producers of bokhasi intend to improve the quality of the product that is improving the quality of bokhasi nutrient content and quality of product packaging. Bokhasi products so far will be upgraded to bokhasi plus by means of enrichment to produce bokhasi products with high nutrient content. Improving the quality of packing that was originally packed with used sacks will be enhanced to be a more attractive bokhasi packaging with the letters of hosi composition. Another problem is the desire of group members to obtain additional income beyond the main income as a palm oil planters by way of cultivation of chili plants by utilizing bokhasi plus as fertilizer because chili commodity has a promising sale value. The ultimate goal of both programs for both partners is to earn additional income from the cultivation of pepper plants and as a bokhasi plus producer apart from its main income of palm oil production. Benefits of activities that will be perceived by Partner One are able to be a stable and sustainable bokhasi plus producer with more quality products and packaging. Benefit for Partners Two after attending this program is able to become a producer of chili to get additional income other than its main income from the cultivation of palm. The main output of this program is the additional articles and outcomes of products as a tangible form of sustainable economic productive endeavors from both Partners. The first partner is the production of bokhasi plus the interesting packaging with the content of nutrient. The second partner is expected to all members of the women's group of farmers get additional income from chili cultivation.
\end{abstract}

Keywords: bokhasi plus application, packaging, chili cultivation

\section{PENDAHULUAN}

Kelompok Wanita Tani (KWT) Desa Babatan adalah kelompok wanita tani yang sudah berdiri sejak tahun 2013 dengan nama kelompok wanita tani Padang Baru Desa Babatan Kecamatan Sukaraja Kabupaten Seluma. Kelompok ini telah menjadi mitra dalam kegiatan Pengabdian Skim Iptek Bagi Masyarakat (IbM) sejak tahun 2014. Hasil pengabdain yang dilakukan oleh Tim Pengabdian dari Universitas Hazairin telah mampu membuat kelompok wanita tani tersebut mempunyai pengetahuan dan ketrampilan untuk mengolah limbah pertanian yang ada disekitar lingkungan tempat tinggal menjadi produk yang bermanfaat. Pada tahun 2015 kelompok wanita tani desa Babatan masih menjadi mitra dalam kegiatan pengabdian Skim Iptek Bagi Masyarakat yang bertujuan untuk 
memantapkan kelopok ini untuk menjadi produsen bokhasi dengan cara membantu menyediakan alat pencacah (Cooper) sehingga kelopok menjadi lebih produktif dalam memproduksi bokhasi.

Pada tahun 2017 KWT Padang Baru tetap dipilih untuk menjadi mitra satu. Mitra Satu adalah mitra penghasil bokhasi yang selama ini telah mampu menjadi produsen bokhasi dengan produk yang telah dipasarkan dengan kemasan yang sederhana. Berdasarkan hasil penelitian Nurlianti dan Prihanani (2015) dihasilkan bahwa bokhasi dapat ditingkatkan kandungan haranya dengan perlakuan pengayaan nutrisi sehingga bokhasi yang dihasilkan menjadi lebih tinggi kandungan haranya. Kelompok Mitra Satu dan Tim Pengabdian Unihaz menyepakati memilih program kegiatan pengabdian pada tahun 2017 yaitu membuat Bokhasi Plus dengan mengaplikasikan hasil penelitian di atas kemudian melakukan pengemasan produk bokhasi plus tersebut dengan mencantumkan lebel kandungan haranya sehingga konsumen dapat mengetahui komposisi bokhasi yang dibelinya.

Program kegiatan ini dimaksudkan agar kelompok mitra dapat meningkatkan nilai jual produk bokhasinya menjadi lebih bermutu dalam kandungan haranya dan lebih bermutu dalam pengemasan sehingga nilai jual produk akan menjadi lebih tinggi. Sebelumnya kelompok mitra ini menghasilkan bokhasi biasa bukan bokhasi plus dengan produksi yang cukup banyak karena telah dibantu dengan mesin pencacah tandan sawit dari Tim Pengabdian unihaz.

Mesin pencacah atau Cooper berbahan bakar bensin dibuat sedemikian rupa sehingga dapat digerakan secara leluasa di perkebunan sawit untuk menghancurkan tandan sawit yang dipangkas oleh pekebun setiap dua minggu sekali bersamaan dengan waktu panen buah sawit. Hasil pencacahan yang dilakukan oleh mesin ini sangat halus sehingga lebih mudah terdekomposisi dan juga hasil pencacahan langsung dimasukan dalam karung untuk diolah sebagai bahan baku bokhasi.

Kegiatan pencacahan pelepah sawit yang dilakukan di dalam kebun memberikan keuntungan bagi kebuh sawit karena kebun menjadi lebih bersih dan tidak ditemukan lagi tumpukan pelepah sawit di dalam kebun. Tumpukan pelepah sawit yang dipangkas setiap menjelang panen buah sawit merupakan sumber serangan hama Kumbang Tanduk (Oriychetes rhinoceros) yang menyerang tajuk tanaman dan penyakit yang menyerang akar sawit yang disebabkan oleh jamur Genoderma Sp (Firmansyah, 2010).

Bahan baku bokhasi selain tandan sawit juga limbah ternak ayam ras yang potensinya di daerah ini cukup berlimpah karena lokasi kebun sawit dan lokasi peternakan ayam ras berskala besar dalam satu lokasi yang sama pada desa ini sehingga produksi bokhasi akan terus dapat berlanjut tanpa ada kendala. Selain itu dengan memanfaatkan limbah ternak akan membuat sanitasi kandang dan lingkungan sekitar menjadi lebih sehat.

Mitra Dua adalah kelompok wanita tani Padang Baru desa Babatan yang anggotanya berbeda dengan kelompok Mitra Satu. Program yang dilaksanakan pada kelompok Mitra Dua adalah mengaplikasikan bokhasi Plus produk Mitra Satu untuk dicobakan pada tanama cabe karena selain nilai jual dari tanaman ini sangat menjanjikan juga tanaman cabe membutuhkan kandungan hara yang cukup tinggi dibandingkan tanaman jenis sayuran sehingga perlu dilakukan uji coba bokhasi plus yang dihasilkan dengan pengayaan unsure hara untuk budidaya tanaman cabe.

Kelompok Mitra Dua serta Tim Pengabdian Unihaz menyepakati program kegiatan ini atas permintaan dari anggota kelompok untuk mencobakan bokhasi plus pada tanaman pertanian yang diarahkan pada pertumbuhan generatifnya yaitu panen buah cabe. Selain itu juga untuk menguji kemampuan produk Bokhasi Plus tersebut sehingga konsumen akan 
lebih yakin dalam membeli produk Bokhasi Plus karena telah dibuktikan penggunaannya pada berbagai tanaman sayur baik yang dipanen bagian vegetatifnya maupun bagian generatifnya (Nurlianti dan Prihanani, 2016).

Permasalahan yang dihadapi oleh kelompok mitra adalah keinginan dari anggota kelompok untuk mendapatkan pengahasilan tambahan diluar penghasilan utama sebagai pekebun sawit yaitu dengan cara budidaya tanaman cabe dengan memanfaatkan bokhasi plus sebagai pupuk karena komoditas cabe mempunyai nilai jual yang menjanjikan.

Manfaat kegiatan yang akan dirasakan oleh Kelompok Mitra Satu adalah kemantapan sebagai produsen bokhasi plus dengan membuat kemasan produk yang lebih menarik dan lebih komunikatif dengan mencantumkan label komposisi hara yang dikandungnya. Manfaat program kegiatan bagi Mitra Kedua adalah sebagai produsen tanaman cabe dapat menambah pendapatan ekonomi keluarga. Manfaat bagi lingkungan adalah sanitasi kebun yang semakin baik sehingga sanitasi lingkungan rumah juga menjadi lebih baik karena masyarakat tinggal di dalam perkebunan sawit sehingga sanitasi kebun juga adalah sanitasi pemukiman bagi mereka.

Luaran kegiatan dari program ini adalah bentuk nyata usaha ekonomi produktif yang berkelanjutan dari kedua kelompok tani yang menjadi Mitra Program IbM. Mitra Pertama luaranya adalah produksi bokhasi plus dengan pengemasan yang menarik dengan mencantumkan kandungan haranya. Luaran Mitra kedua diharapkan seluruh anggota kelompok wanita tani mendapatkan penghasilan tambahan dari budidaya cabe merah.

\section{METODE PENGABDIAN}

Metode pelaksanaan program ditawarkan dalam bentuk program- program kegiatan yang meliputi beberapa kegiatan yaitu pendampingan untuk mitra satu dalam memproduksi bokhasi plus dan pendampingan membuat kemasan yang menarik dengan cara membuat disain lebel kemasan dan melakukan analisis kandungan hara dari bokhasi plus yang dihasilkan di laboratorium untuk dicantumkan dalam kemasannya.

Metodologi program kegiatan untuk mitra dua adalah pelatihan dan pendampingan teknologi Budidaya Cabe. Kegiatan dapat dikelompokkan dalam 2 sub kegiatan yaitu; (1) Pelatihan teknis budidaya cabe; (2) Demontrasi Plot Budidya Cabe. Dalam semua pelaksanaan kegiatan di atas dilaksanakan bersama antara Tim Pengabdian dari Fakultas Pertanian Unihaz dan kedua kelompok Mitra dengan pembagian kerja yang telah disepakati serta mahasiswa pertanian unihaz yang diikut sertakan sebagai sarana bagi mahasiswa untuk mendapatkan ketrampilan dalam kegiatan usaha tani budidaya cabe.

\section{HASIL DAN PEMBAHASAN}

\section{Produsen Bokhasi Plus Pada Mitra Satu}

Progam yang telah dilaksanakan pada Mitra Satu adalah pemantapan sebagai produsen bokhasi dengan cara meningkatkan mutu produk yaitu meningkatkan kandungan hara sehingga disebut sebagai pupuk Bokhasi Plus. Kegiatan lainnya adalah melakukan pengemasan produk hingga lebih menarik dan komunikatif. Produk bokhasi telah di pasarkan namun masih dalam kalangan terbatas setelah melaksanakan program ini maka pemasaran produk diharapkan lebih lancar dan produk lebih dikenal oleh masyarakat. Pemasaran produk yang baik akan berdampak pada keberlangsungan produksi bokhasi plus selanjutnya. 
Pertanian terpadu yang menggabungkan budidaya sawit dan peternakan menghasilkan produksi bokhasi dari limbah pertanian. Hasil penelitian Nurlianti dan Prihanani (2015) melaporkan bahwa pembuatan bokhasi yang dihasilkan dari limbah pertanian yaitu limbah kebun sawit dan limbah ternak ayam ras telah menghasilkan bokhasi dengan kandungan hara makro $\mathrm{N} ; 1.66 \%, \mathrm{P}: 0.3 \%, \mathrm{~K}: 1.16 \%$. Bokhasi plus adalah bokhasi yang dihasilkan dengan pengayaan yaitu penambahan pupuk anorganik, sehingga bokhasi yang dihasilkan menunjukkan kandungan hara yang lebih tinggi jika dibandingkan dengan pembuatan bokhasi tanpa pengayaan.

Peranan dari bokhasi sebagai bahan organic akan dapat memperbaiki sifat fisik tanah dan sifat kimia tanah akan diperbaiki secara lambat sesuai dengan pendapat Yulia, Murniati, dan Fatimah (2011) Pupuk organik dapat menyediakan unsur hara dalam waktu yang lama bagi tanaman. Hal tersebut terjadi karena proses pelepasan unsur hara pada pupuk organik bersifat lambat (slow release) sehingga bahan organik tersebut meninggalkan residu setelah dimanfaatkan tanaman pada musim pertama. Residu pupuk organik berpengaruh terhadap pertumbuhan dan peningkatan hasil tanaman pada musim tanam berikutnya.

Pelepah daun kelapa sawit mengandung lignin yang tinggi maka proses pengomposan pelepah daun kelapa sawit membutuhkan waktu lama. Proses dekomposisi pelepah kelapa sawit secara alami membutuhkan waktu yang lama yaitu sekitar 3-4 bulan (Lubis, Mulyono, dan Haryono, 2017) namun dalam kemajuan teknologi maka kekurangan tersebut dapat diminimalkan, antara lain dengan memberikan aktivator yang mengandung mikroba yang sesuai untuk proses pengomposan. Kombinasi mikrobia pada aktivator dan aktivitas mikroba selama proses pengomposan pada berbagai macam aktivator sangat mempercepat lama proses pengomposan dan kualitas kompos. Proses tersebut dapat dipercepat dengan bantuan EM-4 yaitu mikroorganisme lignoselulotik unggul yang tetap bertahan di dalam kompos. Bantuan mikroba decomposer atau activator yang berkemampuan tinggi akan mempercepat proses pengomposan dari beberapa bulan menjadi hanya beberapa minggu (Isori, 2015).

Prosedur pembuatan bokhasi Plus yang telah dilaksanakan oleh kelompok Mitra Satu dapat dilihat pada gambar di bawah ini.
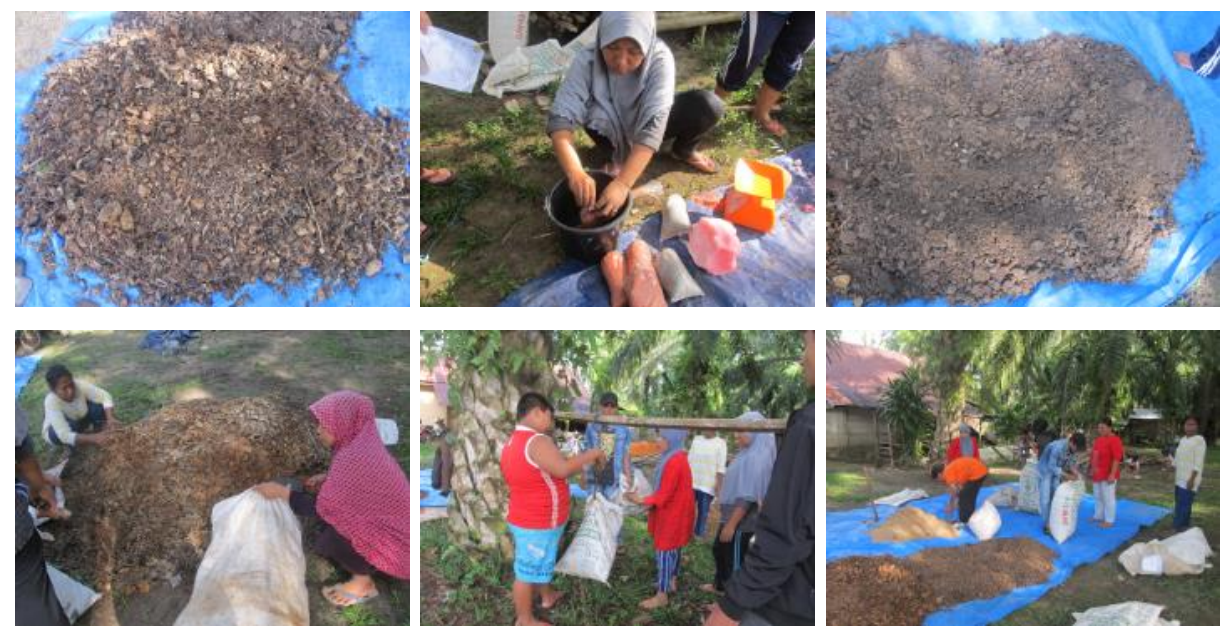

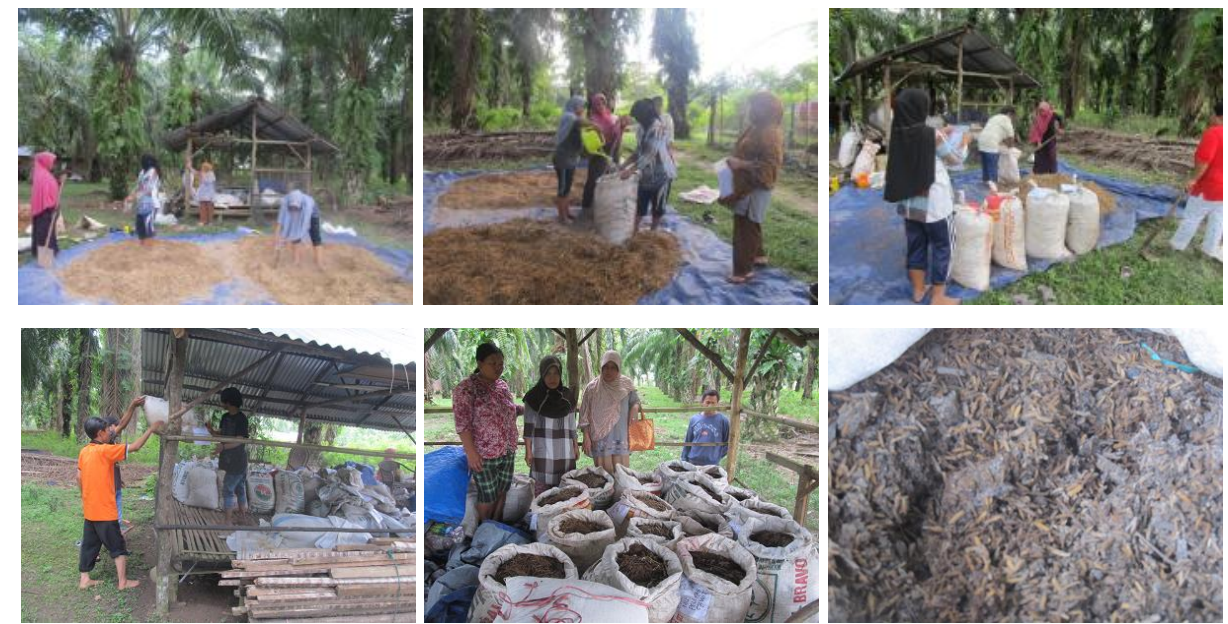

Gambar 1. Prosedur pembuatan bokhasi plus

Produk bokhasi yang telah di hasilkan dikemas dengan kemasan sederhana sehingga kurang menarik. Program kegiatan pada Mitra Satu dilanjutkan dengan Program peningkatan kualitas produk bokhasi dilakukan dengan kegiatan perbaikan pengemasan. Sebelum program dilakukan pengemasan produk masih sederhana dengan menggunakan karung bekas dan setelah program dilaksankan maka pengemasan produk menjadi lebih menarik, dan diharapkan nilai jual produk akan meningkat

Kegiatan pendampingan pengemasan produk bokhasi meliputi kegiatan pembuatan disain kemasan, membeli karung ukuran $20 \mathrm{~kg}$ dengan warna dan bentuk yang seragam, menyablon di atas karung dan selanjutnya karung siap digunakan. Prosedur kegiatan program pengemasan terlihat sebagai berikut:
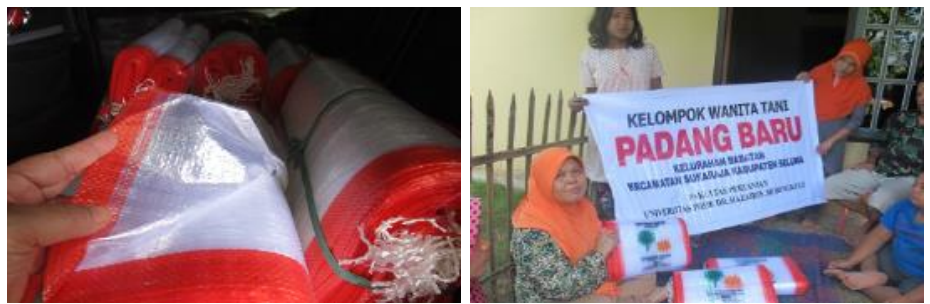

Gambar 2. Karung yang akan disablon
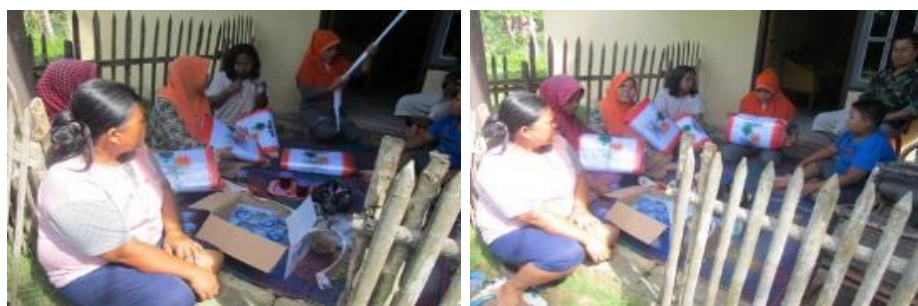

Gambar 3. Penyuluhan pengemasan produk 

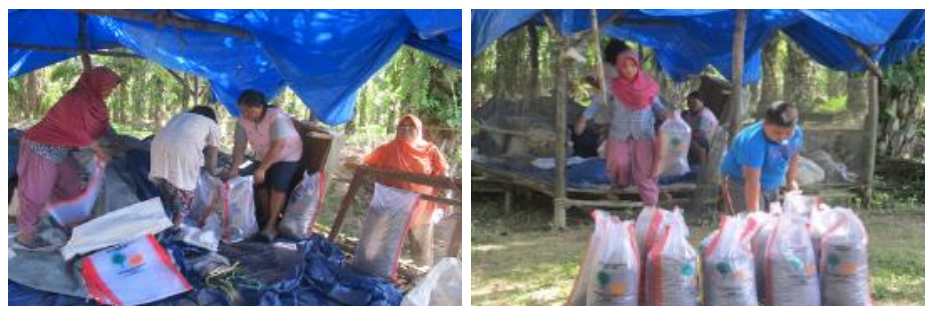

Gambar 4. Kegiatan pendampingan pengemasan produk bokhasi plus
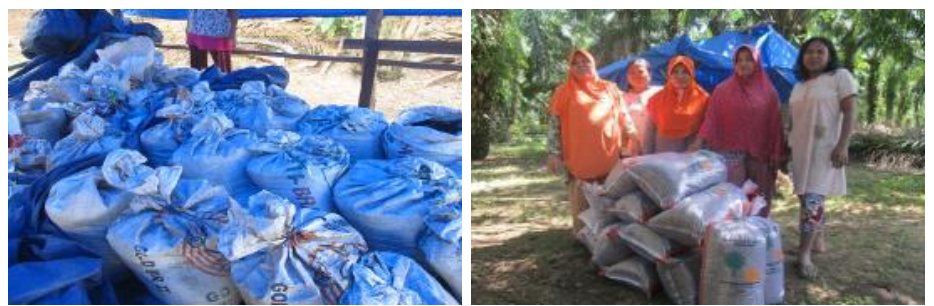

Gambar 5. Produk bokhasi yang dikemas dengan karung bekas dan setelah dikemas dengan karung kemasan

Mitra satu dan mitra dua adalah anggota kelompok wanita tani Padang Baru yang berlokasi di desa Babatan Kecamatan Sukaraja Kabupaten Seluma. Masing-masing anggota Mitra berjumlah 4 orang. Mitra satu adalah adalah kelompok mitra yang dipimpin oleh ibu Rosita sebagai ketua kelompok wanita tani Padang Baru. Mitra Dua adalah kelompok mitra yang dipimpin oleh Ibu Warinengsih. Mitra satu melaksanakan program pembuatan bokhasi plus dan mitra dua melaksanakan program aplikasi bokhasi plus untuk budidaya tanaman cabe merah. Mitra satu yang dipimpin oleh ibu Rosita telah menjadi mitra sejak tahun 2014 hingga tahun 2016. Mitra satu merintis usaha pembuatan bokhasi tahun 2014 hingga menjadi produsen bokhasi tahun 2016.

Berdasarkan kendala lamanya waktu yang dibutuhkan untuk bokhasi plus menjadi matang maka dilakukan uji coba dengan menggunakan pupuk anorganic sebagai bahan penyaanya adalah pupuk Kimia majemuk yaitu pupuk makrostar dengan kandungan NPK =16:16:16 yang berwarna abu-abu. Hasilnya waktu matang bokhasi lebih cepat dengan kandungan air atau kelembaban tidak terlalu tinggi sehingga aroma yang menusuk cepat hilang. Bokhasi sudah dapat digunakan dalam waktu 1 minggu namun bentuk asli bahan baku baik pelepah maupun jerami masih terlihat jelas belum terdekomposisi sempurna. Setelah bercampur dengan media tanah akan dilanjutkan kegiatan mikroorganisme dalam mendekomposisikan bahan dasar sehingga unsur hara yang dibutuhkan siap diserap oleh tanaman.

\section{Aplikasi Bokhasi Plus Untuk Budidaya Cabe Pada Mitra Dua.}

Program yang dilaksanakan pada Mitra Dua adalah aplikasi Bokhasi Plus pada budidaya cabe merah, bertujuan untuk memberi pengetahuan dan ketrampilan kelompok mitra untuk menambah penghasilan dengan melakukan budidaya tanaman cabe. Kelompok mitra sebelumnya adalah kelompok wanita tani yang belum pernah melakukan usaha tani budidaya cabe mereka bekerja di perkebunan sawit sebagai pekebun sawit.

Kegiatan budidayacabe dimulai dengan demonstrasi kegiatan pembibitan, pengolahan lahan, pemulsaan, dan transplanting, pemeliharaan, dan akhirnya panen. Tahapan kegiatan dapat dilihat sebagai berikut: 


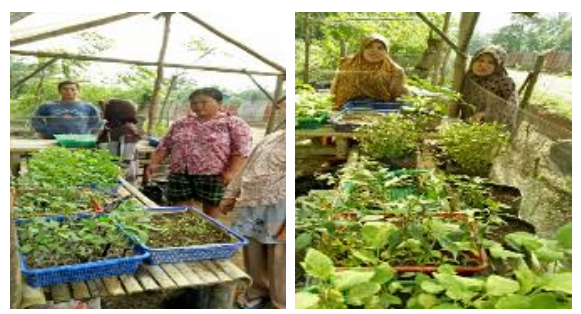

Gambar 6. Pembibitan cabe
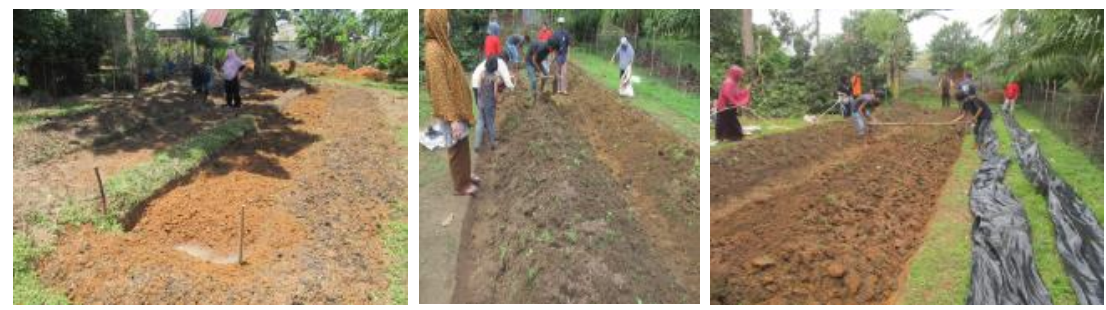

Gambar 7. Pengolahan lahan

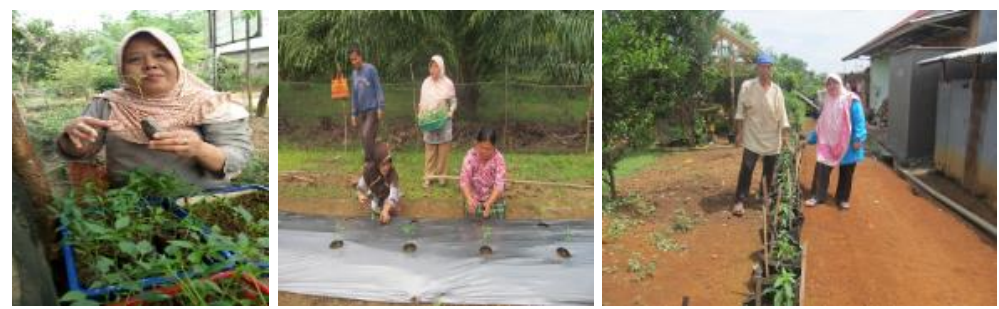

Gambar 8. Kegiatan transplanting bibit cabe ke lapang dan polybag
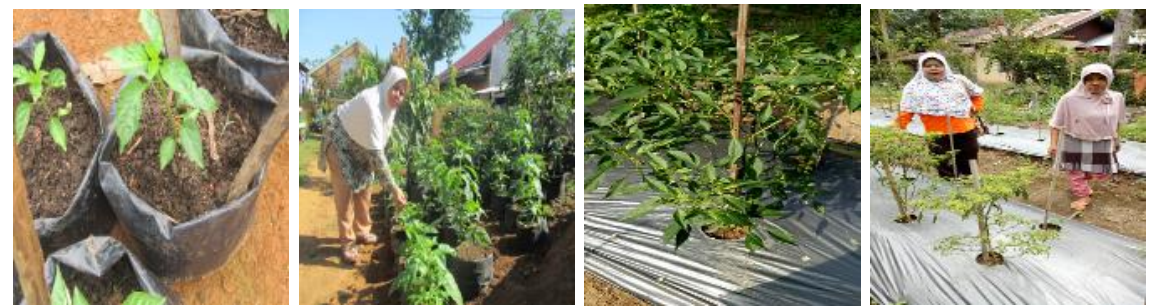

Gambar 9. Pertumbuhan tanaman cabe

Bedengan yang dibuat untuk tanaman cabe sebanyak 2 bedengan dengan pulsa plastic putih perak berukuran masing-masing 1,5 x $6 \mathrm{~m}$. Bedengan tanpa pulsa plstik putih perak sebanyak 2 bedengan dengan ukuran 1,5 x $4 \mathrm{~m}$. Jarak tanam 30 x $30 \mathrm{~cm}$ sehingga jumlah populasi tanaman cabe sebanyak 60 batang pada bedengan dengan pulsa sedangkan tanpa mulsa 40 batang. Tanaman cabe di tanam setiap bedengan berbeda waktunya sehingga diharapkan tanaman akan di panen seca berkala dan kelompok tani dapat menjual produksinya secara berkelanjutan.

Hasil pertumbuhan cabe terlihat tumbuh baik dan sudah mencapai tinggi $25 \mathrm{~cm}$ hingga $30 \mathrm{~cm}$ dan sudah mulai berbunga. Pada sebagian tanaman terlihat adanya serangan virus yang menyebabkan tanaman cabe menjadi kerdil. Pertumbuhan Cabe di Lapang hingga masa vegetative terlihat subur namun setalah memasuki masa berbunga tanaman diserang penyakit keriting daun yang disebabkan oleh virus sehingga menggagu produksi cabe. Pada bedengan pertanaman cabe yang ditanam pertama terlihat pertumbuah cabe terserang penyakit keriting daun hanya 1-2 tanaman saja, namun karena terlambat pemusnahannya maka serangan menyebar ke tanaman lain sehingga praktis tanaman 
hampir mencapai $40 \%$ dari tanaman pada satu bedengan terkena serangan penyakit. Tanaman yang terserang dicabut dan dimusnahkan kemudian di gantikan dengan tanaman terong.

Tanaman cabe yang ditanam di polybag terlihat tumbuh dengan baik. Produksi yang dihasilkan pada tanaman cabe yang pertumbuhannya tidak terganggu dapat memproduksi cabe per batang kisaran 250-300 gram per batang pada panen pertama dan kedua. Penelitian yang dilaporkan oleh Ichwan (2007) produksi cabe merah dengan dosis Trikhompos 15 ton per hektar menghasilkan bobot cabe per batang sebesar 572,03 gram pada panen keempat.

Pada lahan yang diserang penyakit keriting daun maka tanaman dicabut dan diganti dengan tanaman terong yang diharapkan dapat menambah penghasilan keluarga sekaligus dapat memotong rantai penyakit keriting daun pada tanaman cabe. Setelah masa tanam terong berakhir maka lahan kembali akan di tanami tanaman cabe. Usaha pengalihan tanaman ke tanaman terong bertujuan untuk menekan kerugian biaya produksi yang telah di keluarkan oleh mitra. Produksi terong dipanen per minggu dan panen terong pertama menghasilkan 1-2 kg per tanaman dan akan bertambah produksinya sesuai umur tanaman yang semakin meningkat.

Tanaman cabe dan tanaman terong adalah jenis tanaman sayur yang di panen dengan memilih buah yang siap untuk di panen dan panen selanjutnya berjangka waktu sesuai dengan kematangan buah di pohon kurang lebih 4-5 hari sekali. Panen cabe ke-4 akan mencapai puncak produksi dan setelah mencapai puncak kemudian menurun hingga panen ke- 8 produksi sudah sangat menurun hingga tanaman mati.
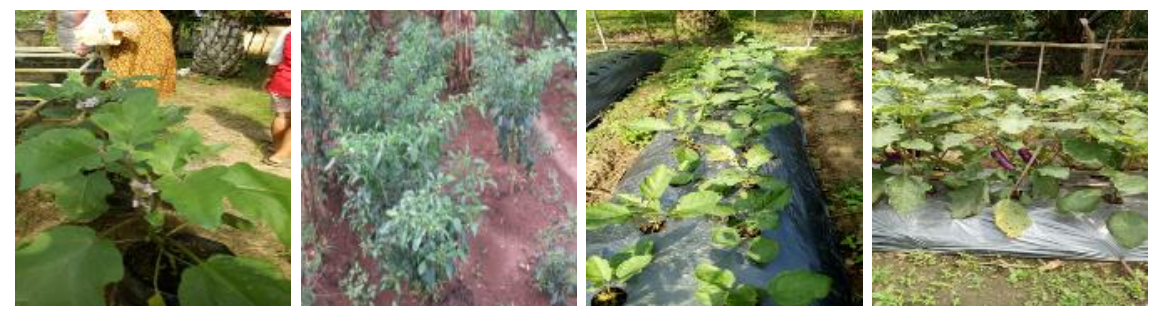

Gambar 10. Pertumbuhan tanaman cabe dan pertumbuhan tanaman terong

Aplikasi bokhasi plus yang telah matang diaplikasikan untuk budidaya cabe adalah upaya dari kelompok mitra untuk meyakinkan diri bahwa produksi bokhasinya dapat digunakan untuk budidaya cabe merah dengan hasil yang baik sehingga mereka merasa yakin untuk mempromosikannya kepada masyarakat yang membeli produknya.

Informasi dari kelompok tani pengguna bokhasi biasa tanpa pengayaan yaitu kelompok wanita tani Panorama yang diaplikasikan pada tanaman sayuran menujukan hasil yang sangat baik terutama pada masa tanam kedua dan selanjutnya. Tanah di daerah ini dikenal dengan nama Podsolik merah kuning dan bersifat masam setelah diberikan kapur kemudian dibiarkan selama 15 hari dan diberikan pupuk bokhasi kemudian dibiarkan selam 15 hari maka terjadi perubahan yang sangat nyata terlihat pada warna tanah yang lebih gelap, lebih gembur, dan tekturnya lebih halus. Semula sebelum diberikan bokhasi tanah terlihat berwarna lebih kuning, lebih liat dan tekturnya pejal tidak remah serta bergumpal. Pengalaman kelompok wanita tani Panorama ini membuktikan bahwa penggunaan bokhasi memperbaiki sifat fisik tanah dan residu pupuk organic akan dimanfaatkan oleh tanaman pada musim tanam selanjutnya sesuai dengan pendapat yang dilaporkan oleh (Yulia, Murniati, dan Fatimah, 2011). 


\section{Pemasaran Produk Bokhasi Plus}

Pemasaran bokhasi Plus selama ini dipasarkan dari mulut ke mulut dan belum ada usaha yang sunguh-sunguh untuk pemasaran produk. Setelah produksi semakin banyak maka dicoba dilakukan dengan pemasaran melalui Penyuluh Pertanian (PPL). Penyuluh pertanian biasanya mempunyai kelompok tani binaan masing-masing sehingga melalui perantara mereka akan mudah memberikan keyakinan pada kelompok tani untuk menggunakan produk bokhasi yang dihasilkan oleh Mitra Satu.

Tim pengabdian menjembatani hubungan antara Mitra Satu dengan beberapa kelompok tani melalui PPL sehingga ada beberapa pesanan bokhasi dari beberapa kelompok tani. Kelompok Tani yang berkeinginan untuk membeli bokhasi dari Mitra Satu adalah kelompok Tani yang sangat produktif dalam usaha tani budidaya sayur sehingga kebutuhan akan produk bokhasi sangat besar dan berkelanjutan. Pesanan dari kelompom tani semacam ini membuat Kelompok Mitra Satu sebagai produsen bersemangat dalam mengahasilkan produknya dan berkeyakinan akan prospek usaha yang berkelanjutan.

Pemasaran produk Bokhasi Plus lainnya dilakukan dengan cara promosi melalui kegiatan Kuliah Kerja Nyata yang sedang dilaksanakan oleh mahasiswa Unihaz . Kuliah kerja nyata dilaksanakan di didesa sejak bulan Juli hingga Bulan akhir Agustus 2017. Melalui mahasiswa diharapkan produk bokhasi dapat dikenal dan selain itu melalui program pertanian yang dilakukan oleh mahsiswa yang sedang berada di desa sangat efektif memberikan informasi langsung ke petani dapat melihat hasil tanaman yang mengunakan produk Bokhasi Plus.

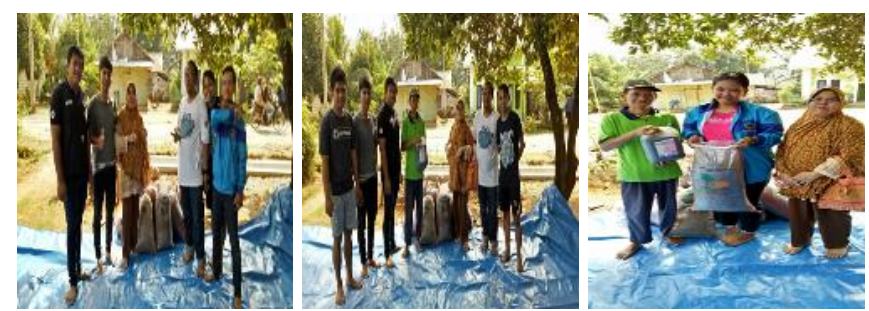

Gambar 11. Penyerahan bokhasi plus kepada peserta kuliah kerja nyata

\section{KESIMPULAN}

Hasil kegiatan program yang direncanakan pada kelompok Mitra Satu telah berhasil menjadikan produk bokhasi menjadi lebih berkualitas ditandai dengan kandungan hara yang lebih baik sehingga disebut menjadi bokhasi plus. Penampilan produk lebih menarik dari sebelumnya dengan adanya informasi pada kemasan tentang nama kelompok wanita tani serta komposisi haranya.

Hasil kegiatan yang direncanakan pada kelompok mitra dua yaitu aplikasi Bokhasi Plus untuk budidaya cabe belum sepenuhnya berhasil untuk menambah pendapatan anggota kelompok berupa produk cabe karena dalam proses penanaman cabe di lapang ada serangan virus sehingga tanaman menjadi keriting daunnya kemudian dilakukan tindakan pemcabutan dan pembakaran agar virus tidak menyebar. Tanaman diganti sebagian dengan tanaman terong yang bertujuan untuk memutus rantai penyakit keriting daun sekaligus dapat menghasilkan tambahan pendapatan bagi anggota kelompok dari produksi tanaman terong. Sementara pada budidaya cabe yang dilakukan di polybag sudah dapat menghasilkan dengan produksi 200-300 gram per tanaman begitu juga pada tanaman di bedengan yang tidak terserang penyakit. 


\section{UCAPAN TERIMA KASIH}

Ucapan terima kasih disampaikan kepada kedua kelompok mitra yang telah ikut serta dalam menjalankan program ini dan khususnya penyandang dana yaitu Direktorat Riset dan Pengabdian Masyarakat Direktorat Jendral Penguatan Riset, dan Pengembangan Kementerian Riset, Teknologi, dan Pendidikan Tinggi Sesuai dengan Surat Perjanjian Penugasan Pelaksanaan Program Pengabdian Nomor: 2541/SP2H/K2/KM/II/2017 Tanggal 10 April 2017.

\section{DAFTAR PUSTAKA}

Firmansyah, A,M, 2010, Pelatihan Petani Plasma Kelapa Sawit. Balai Pengkajian Teknologi Pertanian (BPTP) Sukamara: Kalimantan Tengah.

Ichwan, B, 2007, Pengaruh Dosis Trichokompos Terhadap Pertumbuhan Dan Hasil Tanaman Cabe Merah (Capsicum Annuum L.), Jurnal Agronomi, 11(1).

Isroi, 2005, Bioteknologi Mikroba Untuk Pertanian, Balai Penelitian Bioteknologi Perkebunan Indonesia, repository.unib.ac.id/70/1/Akta\%2013(1)_62-69.pdf Translate this page by S Pamuji-2010.

Lubis, S.S, Mulyono, dan Haryono, 2017, Upaya Mempercepat Pengomposan Pelepah Daun Kelapa Sawit (Elaeis Guineensis) Dengan Berbagai Macam Aktivator. Faperta Universitas Muhamaddyah Yogyakarta: Yogyakarta.

Nurlianti dan Prihanani, 2015, Pengaruh Komposisi Bahan Dasar Bokhasi Plus dan Intensitas Naungan Terhadap Pertumbuhan awal Tanaman Jahe Organik, Jurnal Agroqua, 13(2):46-57

Nurlianti dan Prihanani, 2016, Respon Pertumbuhan Selederi Pada Budidaya Organik Terhadap Penggunaan Jenis Naungan dan Komposisi Media Tanam Bokhasi Plus yang Berbeda, Jurnal Agroqua, 14(2):60-66.

Yulia, A.E, Murniati, dan Fatimah, 2011, Aplikasi Pupuk Organik pada Tanaman Caisim untuk Dua Kali Penanaman, J. SAGU, 10(1):14-19. 